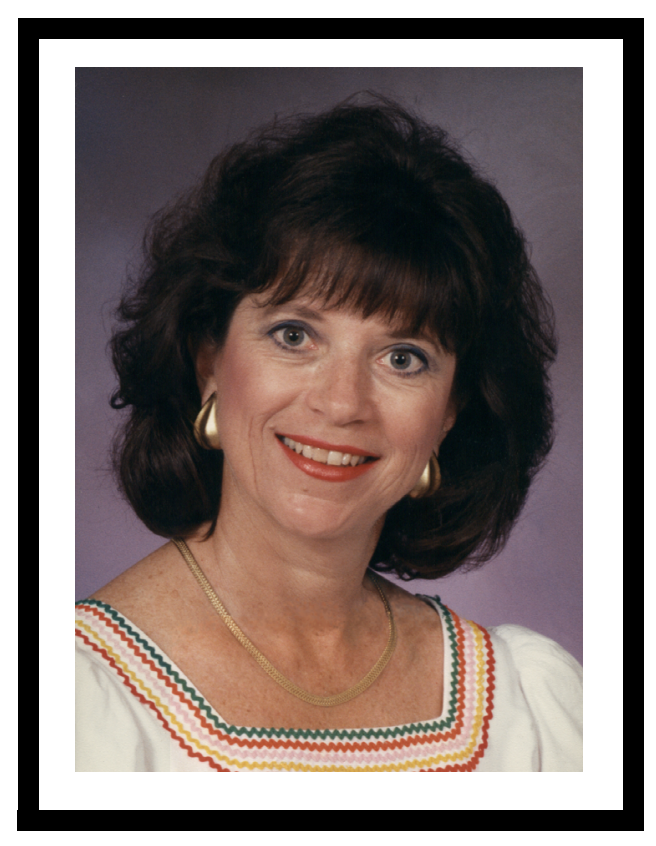

RENEE KRA (1936-2001)

Radiocarbon's former managing editor, Renee Kra, died 14 May 2001 in Tucson. She was 64.

Readers will remember Renee as the dynamic managing editor of Radiocarbon, a position she held for three decades. Friends and colleagues will miss Renee's sense of humor, keen eye for detail, and even her notorious (often copious) editing marks. The journal and its contributors benefitted greatly from Renee's high standards and dedication, as her energy fueled every Radiocarbon project from 1967 to 1996.

Renee Adelle Saltz Kra was born in Rockaway Beach, New York on 18 December 1936. She received a bachelor's degree in English from City College of New York in 1957 and later attended the University of Lausanne, Switzerland as well as Brooklyn College, Yale University, and finally New York University, where she received a master's degree in Anthropology in 1979.

Renee taught social studies, English, and French in the late 1950s and early 1960s in New York and Switzerland. From 1964 to 1967, she worked as an editorial assistant on several projects at Yale University. At that time, Yale was the home of Radiocarbon, and Renee was hired as managing editor of the journal in 1967.

In 1989, Radiocarbon changed hands from Yale to the University of Arizona, and Renee together with "her" journal, made the 3500-km move from New Haven to Tucson, Arizona. At the same time, Renee was overseeing publication of the 850-page proceedings of the 1988 Dubrovnik radiocarbon conference. Renee succeeded in publishing the volume on time in 1989 and immediately began to help with the organization of the next radiocarbon conference, held in Tucson in 1991. Whatever the task-coordinating the conference tennis tournament (which she won), planning a barbecue for over 200 attendees (and new friends), or even cleaning up afterwards (trash bag in hand, kerchief on head)—Renee showed enthusiasm and dedication.

Another of Renee's major projects was the International Radiocarbon Data Base (IRDB). In response to queries from numerous researchers looking for specific dates published in Radiocarbon 
(or perhaps not published anywhere), Renee set out to compile all the available dates and related details into one database. She published several papers about the IRDB (Kra 1985, 1986, 1988, 1989a, 1989b; Walker and Kra 1989). As director of the project, she met with researchers and data management experts to discuss how to compile the information, maintain the database, and raise necessary funding. An additional concern was that radiocarbon dating by the new accelerator mass spectrometry (AMS) method would create thousands of new dates every year. Therefore, keeping the database current would be challenging and probably expensive. In the end, despite years of planning, Renee never saw the IRDB become a reality, as the project was shelved in the early 1990s due to a lack of funding.

Renee also worked hard to expand Radiocarbon's publishing services. In the late 1980s and early 1990s, the journal staff produced the books Radiocarbon After Four Decades, LSC 92 and LSC 94 (proceedings of the 1992 and 1994 Liquid Scintillation Spectrometry Conferences), and Late Quaternary Chronology and Paleoclimates of the Eastern Mediterranean. And Renee's legacy continues, as LSC 2001 will be published next year.

During her last few years at Radiocarbon, Renee persevered through several personal triumphs and setbacks (see her 1996 editorial). In 1995, Renee was diagnosed with lung cancer, but she continued to manage the journal while undergoing radiation and chemotherapy treatments. Shortly after beating the lung cancer, Renee successfully underwent surgery for a brain tumor. Finally, taking a much deserved rest, Renee retired from the journal in 1997.

Renee regretted not being able to take part in the two most recent radiocarbon conferences (in the Netherlands and Israel), as she had always enjoyed catching up with old friends and learning about the latest developments in the radiocarbon field. Renee's office walls were covered with photos, postcards, and notes from her friends in the radiocarbon world, many of whom she had met at conferences.

Some of Renee's closest friends and colleagues contributed to a special issue of Radiocarbon published in her honor last year ( $\mathrm{Vol} 42, \mathrm{Nr} 1,2000)$. When I visited her just two weeks before her death, she mentioned again how touched she had been by the contributors' messages. In fact, I had stopped by her house to give her several more copies of the issue, which she planned to distribute to friends and family.

Renee passed away after suffering a stroke at her home in Tucson. She is survived by her mother, Martha Saltz, daughters Lisette Kra and Annice Kra, and sister Lori Fink.

All of us at Radiocarbon will miss Renee greatly, as I am sure will her worldwide circle of friends.

\section{Kim Elliott}

\section{REFERENCES}

Kra R. 1985. Standardizing procedures for collecting, submitting, recording and reporting radiocarbon samples. North American Archaeologist 6(3):245-55.

Kra RS. 1986. Report of the ${ }^{14} \mathrm{C}$ data base workshop. $R a$ diocarbon 28(2A):800-2.

Kra RS. 1988. First American workshop on the International Radiocarbon Data Base. Radiocarbon 30(2): 259-60.

Kra RS. 1989a. The International Radiocarbon Data
Base: a progress report. Radiocarbon 31(3):1067-76. Kra RS. 1989b. Report of the International Radiocarbon Database Workshop. Radiocarbon 31(3):1080-2.

Kra RS. 1996. To all my friends. Editorial. Radiocarbon 38(2):iii.

Walker AJ, Kra RS. 1989. Report on the International Radiocarbon Data Base (IRDB) workshop, archaeology and ${ }^{14} \mathrm{C}$ Conference, Groningen, the Netherlands. Radiocarbon 30(2):255-8. 